NBER WORKING PAPER SERIES

\title{
PRODUCTION, FINANCIAL STRUCTURE AND PRODUCTIVITY GROWTH \\ IN U.S. MANUFACTURING
}

Jeffrey I. Bernstein

M. Ishaq Nadiri

Working Paper No. 4309

\author{
NATIONAL BUREAU OF ECONOMIC RESEARCH \\ 1050 Massachusetts Avenue \\ Cambridge, MA 02138 \\ March 1993
}

This paper is part of NBER's research program in Productivity. Any opinions expressed are those of the authors and not those of the National Bureau of Economic Research. 
NBER Working Paper \#4309

March 1993

\section{PRODUCTION, FINANCIAL STRUCTURE \\ AND PRODUCTIVITY GROWTH \\ IN U.S. MANUFACTURING}

\section{ABSTRACT}

The purpose of this paper is to estimate a model that incorporates the effects of financial decisions on production, profitability, and productivity growth. Asymmetric information generates agency costs of debt and signaling benefits of dividends which then influence production decisions. The model is applied to the U.S. manufacturing sector.

Agency costs and signaling benefits are measured by their effects on profitability. A one percent increase in debt reduces variable profit by 0.04 percent, while a one percent increase in dividends raises variable profit by 0.12 percent. Agency costs also limit the adjustment of U.S. manufacturing to long-run equilibrium. On average, for $\$ 1.00$ of funds raised through bond issues, debt adjustment cost is about \$0.05. The dynamic efficiency of the manufacturing sector is affected by financial considerations. Signaling benefits contribute 4.2 percent to total factor productivity growth, while agency costs reduce efficiency by 3.3 percent. Thus the financial effects on dynamic efficiency approximately offset each other.

Jeffrey I. Bernstein Department of Economics Loeb Building, 8th Floor Carleton University Ottowa, Ontario, K1S 5B6

CANADA and NBER
M. Ishaq Nadiri Department of Economics New York University 269 Mercer Street, 7th Floor New York, NY 10003 U.S.A. and NBER 


\section{INTRODUCTION}

The major purpose of this paper is to investigate how financial decisions affect production, profitability, and productivity growth. In particular, the focus is on the impact arising from the agency costs associated with debt and the signaling benefits of dividends. Output supply and input demand are influenced by financial structure due to the existence of asymmetric information among equity and debt holders. Asymmetric information generates incentive conflicts among the various claimants to the flow of funds. These incentive conflicts give rise to the agency costs of bond financing and to the signaling benefits of dividend payments, which in turn affect production decisions.

In the theoretical literature the existence of informational imperfections has provided the means to generate interdependencies between production and financial structure (see the survey by Fazzari, Hubbard in Petersen (1988) and references therein).' More recently Kim and Maksimovic (1990) examine the effect of agency costs on productivity growth for the U.S. airline industry, and Greenwald, Kohn and Stiglitz (1990) look at the influence of agency costs on productivity growth for the U.S. private sector. Generally, in this literature, debt levels are determined through a tradeoff between agency costs and tax shields, while dividends are set by a trade-off between $\operatorname{tax}$ disadvantages and signaling benefits. There is little empirical evidence regarding the magnitudes of agency costs and signaling benefits and their effects on production, profitability and productivity growth. The focus of this paper is to provide empirical evidence on these issues, as they relate to the U.S. manufacturing sector.

The framework that we adopt integrates production technology with debt agency costs and dividend signaling benefits. In developing the model we show how duality theory can be extended to allow for the interdependencies between production and financial decisions. ${ }^{2}$ The significance of the dual approach is that production and financial decisions are simultaneously modelled. Thus, for example, the tax cost of dividends affects output supply and input demand, while conversely, output and input prices (or in other words, revenue and production cost) affect dividend payments. The model is a set of simultaneous equations consisting of the equilibrium conditions of output, variable inputs, capital, debt and dividends. These conditions define a temporary equilibrium, as there are 
costs of adjustment to long-run equilibrium. ${ }^{3}$ In this paper there are two costs that limit adjustment to long-run equilibrium. The first type of cost is associated with the installation of capital. Capital installation cost is the traditional source of a dynamic adjustment process. The second source arises from capital financing and is defined by the agency costs from debt issues. In this paper we estimate adjustment costs from both capital installation and debt issues for U.S. manufacturing.

Financial structure affects output supply, input demand, and therefore allocative and dynamic efficiency. We measure the effects of financing decisions on profit and productivity growth for the U.S. manufacturing sector. TFP growth is the difference between output and input growth rates and traditional measures of TFP growth can be decomposed into technological change and returns to scale components. In this paper, the decomposition of TFP growth is extended to show how both debt financing and dividend payments influence dynamic efficiency for the U.S. manufacturing sector.

This paper is organized in the following manner: In section 2 the model is developed. Section 3 contains a discussion of the data and the estimation results. In section 4, results are presented on the interrelationship between production, profitability, and financing. In section 5 are estimates of the adjustment costs associated with capital installation and debt financing. Section 6 pertains to the effects of signaling benefits and agency costs on the decomposition of TFP growth. The last section of the paper is the conclusion. 


\section{THE MODEL}

A production process can be represented by the function

$$
y(t)=F\left(v(t), v^{m}(t), K(t-1), \Delta K(t), t\right)
$$

where $y$ is output, $F$ is the production function, $v$ is an $n$-dimensional vector of variable inputs, $v^{m}$ is the managerial input, $\mathrm{K}$ is the capital input, $\Delta \mathrm{K}$ is the change in the capital input, and $\mathrm{t}$ is the indicator of technology that also represents the time period. ${ }^{4}$ The managerial input relates to the services of planning, organizing, and monitoring inputs in order to facilitate technologically efficient production (See Maksimovic (1986) and Brander and Spencer (1989) for a discussion of managerial in puts and financial structure.). Capital adjustment costs are represented by the changes in the capital input. In order to install the capital input into the production process, adjustment costs are incurred and these costs are manifested by the foregone output from the diversion of resources to capital installation."

Managerial decisions cannot be costlessly monitored by shareholders and bondholders. The asymmetric information between managers and financiers cause incentives to diverge between the agents. Leland and Pyle (1977), Ross (1977), Bhattacharyya (1979), Myers and Majluf (1984), and Bernheim (1991) treat share issues and dividend payments as signaling devices. Firms pay dividends to signal that there is an adequate net flow of funds. Indeed, firms pay dividends and make up any shortfall in funds with share issues. The signaling benefits of dividends are traded-off against the higher taxes associated with dividend payments (see King (1977), Auerbach (1979), and Poterba and Summers (1985)).

Asymmetric information causes bond issues to be a source of agency costs. Jensen and Meckling (1976), Stiglitz and Weiss (1981), and Greenwald, Kohn and Stiglitz (1990) have shown that, in the context of asymmetric information, firms can undertake comparatively risky investment projects that increase the exposure of creditors. Myers (1977) also suggests that debt is costly because it causes firms to pass up profitable investment projects. The reason is that part of the benefits of a project accrue to creditors while shareholders bear the costs. Debt issues result in agency costs traded of against the tax reduction associated with interest payments on debt. 
In order to capture the signaling benefits of dividends and agency costs associated with debt, we define a managerial cost function,

$$
c^{m}(t)=\mu H(D(t), B(t-1), \Delta B(t))
$$

where $\mathrm{c}^{\mathrm{m}}$ is managerial cost, $\mu$ is the managerial input price, $\mathrm{D}$ is dividends, $\mathrm{B}$ is the value of outstanding bonds, and $\Delta B$ is the value of new bonds. ${ }^{6}$ The costs of debt and the benefits from dividends are manifested by the function, $\mathrm{H}$, which is decreasing in debt and increasing in dividends.' One aspect of a manager's organizing function is to obtain financing for the firm. The ability to raise funds will be enhanced if a firm pays higher and sustained dividends, while its ability to raise funds is reduced if its existing debt is high or if it goes to the bond market for new debt. In this model there are agency costs associated with both outstanding debt and new bond issues. The latter are referred to as debt adjustment costs.

The $\mathrm{H}$ function can be considered to be a financing ability function. As financing ability increases, the demand for managerial services increases and so managerial input cost rises. Conversely, as financing ability decreases, managerial input demand decreases. Formally the link between managerial input demand and the $\mathrm{H}$ function can be derived from an application of Shephard's Lemma (see Diewert (1982)). Indeed, $v^{m}(t)=\partial c^{m}(t) / \partial \mu=H(D(t), B(t-1), \Delta B(t))$. Thus the function $\mathrm{H}$ is the managerial input demand function. Substituting the managerial input demand function for $v^{m}(t)$ in the production function yields

$$
y(t)=\mathscr{F}(\mathrm{v}(\mathrm{t}), \mathrm{D}(\mathrm{t}), \mathrm{B}(\mathrm{t}-1), \mathrm{K}(\mathrm{t}-1), \Delta \mathrm{K}(\mathrm{t}), \Delta \mathrm{B}(\mathrm{t}), \mathrm{t})
$$

Equation (3) depicts an augmented production function that includes financial variables. $\mathscr{F}$ is a production cum managerial function, since it represents both the production process and managerial cost. From (3), we see that debt and dividends affect output and input quantities. An increase in outstanding debt lowers managerial demand, which in turn decreases output (given nonmanagerial inputs). In addition, given output, changes in the level of outstanding debt affect both capital and noncapital inputs. Changes in new debt issues and dividends also generate output 
and input effects through the same mechanism.

Capital stock accumulates by

$$
K(t)=I(t)+(1-8) K(t-1)
$$

where $0<8<1$ is the fixed depreciation rate and $I$ is investment.

The flow of funds relating production and financing decisions is

$$
P_{1}(t) y(t)-P^{T}(t) v(t)-Q(t) I(t)-R(t) B(t-1)+\Delta B(t)+\Delta S_{n}(t)-D(t)=0
$$

where $P_{1}$ is the post-tax price of output, $P^{T}$ is the vector of post-tax variable factor prices, $Q$ is the post-tax purchase price of capital, $R$ is the post-tax interest rate on debt, and $\Delta S_{n}$ is the value of share issues."

Production and financing decisions are determined by the maximization of the expected discounted value of equity. Thus, the problem is to

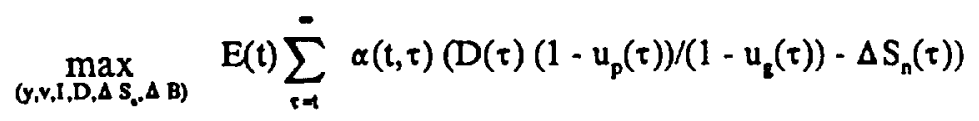

subject to equations (3) - (5), with given initial capital and debt levels. The discount factor is $\alpha(t, t)=$ $1, \alpha(t, t+1)=\left[\left(1+\left(p(t+1)\left(1-u_{p}(t+1)\right) /\left(1-u_{z}(t+1)\right)\right)\right]^{-1}\right.$, where $p$ is the discount rate, $u_{p}$ is the personal income tax rate, and $u_{z}$ is the capital gains tax with $0<u_{z}<u_{p}<1$. Shareholders are subject to dividend taxation at the personal income tax rate (see Poterba and Summers (1985)).

The intertemporal production and financing problem can be solved in two stages. The first stage relates to the determination of the short-run equilibrium. The short-run equilibrium is obtained from 
(7) $\quad \max _{(,, v, D)} P_{1}(t) y(t)-P_{2}(t) D(t)-P^{T}(t) v(t)$

subject to equations (3) and (5) conditional on capital stock and debt levels; where $P_{2}=\left(u_{p}-u_{z}\right) /(1$ $\left.u_{g}\right)>0$ can be considered the price of dividends, which is the additional tax shareholders incur per dollar of dividends relative to receiving a dollar of capital gains. In the short run post-tax variable profit net of dividends is maximized by selecting output, variable factors and dividends. In particular, the tax cost associated with dividends is offset at the margin by the signaling benefits through greater managerial ability to finance production. Conditional on capital stock and debt levels, dividend payments are determined simultaneously with output supply and variable factor demand. Thus, post-tax output and variable factor prices influence dividend payments, and conversely the price of dividends affects output supply and variable factor demand.

Another way that financial variables affect production in the short run is through debt levels. Changes in debt alter the supply of output through the marginal product of managerial input, and also debt affects the demand for the variable factors through the rate of substitution between these inputs and managerial input. In addition, changes in debt influence dividend payments, as agency costs affect signaling ability. Lastly, in the short run, capital accumulation and technological change affect the relative marginal product of the managerial input, and hence dividend payments change as a consequence.

The solution to the problem defined by (6) yields a post-tax net (of dividends) variable profit function,

$$
\phi^{v}(t)=\Phi\left(P_{1}(t), P_{2}(t), P^{T}(t), K(t-1), B(t-1), \Delta K(t), \Delta B(t), t\right)
$$

In order to empirically implement the model a functional form must be assumed for the post-tax net variable profit function. ${ }^{10}$ We assume that the functional form is translog (see Jorgenson (1986)) 
(9)

$$
\begin{aligned}
& \ln \left(\phi^{2} / P_{n+2}\right)=\beta_{0}+\sum_{i=1}^{n+1} \beta_{i} \ln \left(P_{i} / P_{n+2}\right)+\sum_{k=k}^{B} \beta_{k} \ln K_{k}+\beta_{i} t \\
& +.5\left[\sum_{i=1}^{n+1} \sum_{j=1}^{n+1} \beta_{i j} \ln \left(P_{i} / P_{n+2}\right) \ln \left(P_{j} / P_{n+2}\right)+\sum_{k=K}^{B} \sum_{t=K}^{B} \beta_{k d} \ln K_{k} \ln K_{t}+\beta_{n t} t^{2}\right] \\
& +\sum_{i=1}^{n+1} \sum_{k=K}^{B} \beta_{i k} \ln \left(P_{i} / P_{n+2}\right) \ln K_{k}+\sum_{i=1}^{n+1} \beta_{i l} \ln \left(P_{i} / P_{n+2}\right) t+\sum_{k=K}^{B} \beta_{k l} \ln K_{k} t
\end{aligned}
$$

where $P_{1}$ is the post-tax output price, $P_{2}$ is the dividend price, $P_{3}, . ., P_{n+2}$ are the post-tax variable factor prices, $K_{K}$ is capital, $K_{B}$ is debt and $\beta_{i j}=\beta_{j i}, \beta_{k t}=\beta_{k}$. The net (of dividends) variable profit function is homogeneous of degree one in prices. In order to impose this condition, net variable profit and prices are normalized by a variable factor price. "It is assumed that when net investment and new bond issues are zero then marginal capital and debt adjustment costs are zero. $^{12}$ This assumption has the effect of making adjustment costs separable from the other components of net variable profit. Thus adjustment costs are defined as

$$
c^{2}=.5 \sum_{k=k}^{B} \sum_{i=k}^{B} \alpha_{k i} \Delta K_{k} \Delta K_{l}
$$

where $\alpha_{k t}=\alpha_{\alpha}, \Delta \mathrm{K}_{\mathrm{K}}$ is the change in capital and $\Delta \mathrm{K}_{\mathrm{B}}$ is the change in debt. In this specification new debt issues affect the marginal adjustment cost of capital and capital expansion affects the marginal adjustment cost of debt. This interaction reflects that new debt is issued in part because of capital stock expansion. ${ }^{13}$

Using the specification of the net variable profit function, the short-run equilibrium conditions can be obtained by an extension of Hotelling's Lemma (see Diewert (1982)) to include dividends

$$
s_{i}=\beta_{i}+\sum_{j=1}^{n+1} \beta_{i j} \ln \left(P_{j} / P_{n+2}\right)+\sum_{k=K}^{B} \beta_{i k} \ln K_{k}+\beta_{i t} t \quad i=1, \ldots, n+1
$$


where $s_{i}=P_{i} y_{j} / \phi^{2}, i=1$ is output, $i=2$ is dividends for which $y_{i}=-D$ and for $i=3, \ldots, n+1$, $y_{i}=-v_{i}$. Equation set (11) shows that in short-run equilibrium the output, dividends and variable factor components of post-tax net variable profit depend on relative prices, capital stock, outstanding debt, and the technology indicator. ${ }^{14}$

The second stage of the production and financing problem relates to the intertemporal aspects. In this stage investment, debt issues and share issues are determined. Using equations (4) and (8), and substituting into (6), the problem is to

$$
\max _{(K(\tau), B(\tau))} E(t) \sum_{\tau=1}^{\infty} \alpha(t, \tau)[\Phi(.)-R(\tau) B(\tau-1)+B(\tau)-B(\tau-1)-Q(\tau)(K(\tau)-(1-\delta) K(\tau-1)] .
$$

In (12) the intertemporal production and financing decisions relate to the determination of the levels of capital and debt. Share issues are determined as a residual in this model. Once the new levels of capital and debt have been determined, then the implied investment and new debt issues can be obtained. Next, substituting the solutions for capital and debt into equation set (11) permits the determination of output supply, dividend payments and variable factor demands. Lastly, using the flow of funds, equation (5), allows us to solve for new share issues. ${ }^{15}$

Substituting the specific form of the post-tax net variable profit and adjustment cost functions into (12) and carrying out the maximization leads to the following Euler equation

$$
\begin{aligned}
& -\alpha_{K K} \Delta K_{K}(t)-\alpha_{K B} \Delta K_{B}(t)-Q(t)+E(t) \alpha(t, t+1)\left(\left[\beta_{K}+\beta_{K K} \ln K_{K}(t)\right.\right. \\
& +\beta_{K B} \ln K_{B}(t)+\sum_{i=1}^{n+1} \beta_{i K} \ln \left(P_{i}(t+1) / P_{n+2}(t+1)+\beta_{K t}(t+1)\right] \phi^{2}(t+1) P_{n+2}(t+1) / K_{K}(t) \\
& \left.+\alpha_{K K} \Delta K_{K}(t+1)+\alpha_{K B} \Delta K_{B}(t+1) \cdot Q(t+1)(1-8)\right)=0
\end{aligned}
$$


(13.2)

$$
\begin{aligned}
& -\alpha_{B B} \Delta K_{B}(t)-\alpha_{K B} \Delta K_{K}(t)+1+E(t) \alpha(t, t+1)\left(\left[\beta_{t}+\beta_{B B} \ln K_{B}(t)+\beta_{K B} \ln K_{X}(t)\right.\right. \\
& \left.+\sum_{i=1}^{n+1} \beta_{i B} \ln \left(P_{i}(t+1) / P_{n+2}(t+1)\right)+\beta_{B t}(t+1)\right] \phi_{V}(t+1) P_{n+2}(t+1) / K_{B}(t) \\
& \left.+\alpha_{B B} \Delta K_{B}(t+1)+\alpha_{K B} \Delta K_{K}(t+1)-R(t+1)-1\right)=0
\end{aligned}
$$

Equation (13.1) relates to capital. It shows that the expected marginal post-tax profit of capital in period $\mathrm{t}+1$ inclusive of expected adjustment cost and post-tax purchase price savings from the previous period undepreciated capital stock is offset against the post-tax contemporary purchase of capital inclusive of marginal adjustment cost. Equation (13.2) relates to debt. It shows that the expected marginal reduction in post-tax profit in period $t+1$ due to the agency costs of debt inclusive of interest payments but net of expected debt adjustment cost savings from issuing debt in the previous period is offset against the current additional funds from a dollar of debt net of marginal debt adjustment costs from issuing the debt. The Euler equations show that capital and debt have opposite effects on variable profit. The benefit of capital is the profit it generates. The benefit of debt is the additional funds flowing to the firm, while profit is reduced due to the agency costs associated with debt. The complete model that is to be estimated consists of equations (9), (10), (11), and (13).

\section{DATA AND ESTIMATION}

The data relate to the U.S. manufacturing sector for the period 1953 to 1986 . The data on quantities and prices of output, labor and intermediate inputs were obtained from the Bureau of Labor Statistics (see Gullickson and Harper [1986] for a detailed description of the data). These data are based on the Census and Annual Surveys of Manufactures, the BLS Current Establishment Survey and the Census of Service industries.

Data on the quantity of output are obtained as a Tomqvist index of gross outputs at the four-digit level from the Census of Manufactures. The output price index is derived implicitly as a ratio of the current value to the quantity of output.

There are two variable factors, labor and intermediate inputs. Labor input is measured in 
terms of payroll hours, estimated, for production workers, on the basis of the BLS Current Establishment Survey. Hours of non-production workers are estimated on the basis of the data underlying the BLS quarterly labor measures for durable and non-durable manufacturing. Hours of proprietors are taken from the BLS Current Population Survey. The labor input is the sum of hours of all persons engaged in production in the manufacturing sector. Labor cost is obtained from the NIPA. The price index of labor is then obtained implicitly from the series on hours and the cost of labor. To convert the wage index into an hourly wage rate, the labor price index is multiplied by the hourly wage rate for 1982 obtained from the President's Economic Report (1988). The labor input quantity is then defined as the reported labor cost divided by the hourly wage rate.

The price of intermediate inputs is derived from a Tornqvist index (normalized at 1982) of the prices of materials, energy and purchased services. The quantity of intermediate inputs is measured as the total cost of materials, energy and purchased services divided by the price index of intermediate inputs.

Data on the price and quantity of energy are constructed from the Census of Manufactures, the Annual Survey of Manufactures and the BLS Producer Price Index (PPI) Survey. Data are available on the quantity and cost of five fuels (electricity, coal, fuel oil, natural gas and miscellaneous fuels) annually from 1973-1981, and about every five years through the rest of the period 1949-1983. For the benchmark years prices are implicitly calculated, interpolated and extrapolated making use of the PPI and annual estimates of the total cost of purchased fuels published in the Annual Survey of Manufactures. Quantity indices are calculated for each type of fuel and then aggregated using a Tornqvist index. The energy price is obtained implicitly as the ratio of energy cost to quantity.

Materials represent all commodity inputs exclusive of fuels but inclusive of fuel-type inputs used as feed stocks (e.g., crude oil consumed by petroleum refining, and coal bought by primary metal refiners for processing into coke). These data are based on Census Bureau series on annual cost of materials, containers, and supplies. Material input quantities are obtained as the sum of 4digit costs of materials, containers and supplies deflated using price series constructed from BLS producer prices and weights computed from BEA input-output tables of the U.S. economy. 
Purchased services are obtained from the input-output tables of the U.S. economy. Service shares are computed as the proportion of the value of production represented by service inputs from annual input-output tables. Next, service costs are obtained by applying the service shares to the Census value of production. Purchased services input quantities are obtained from the cost estimates deflated by prices from either the BLS producer or consumer price survey.

The nominal value of dividends is obtained from the series Cash Dividends Charged to Retained Earnings obtained from the Quarterly Financial Report. The real value of dividends is calculated by deflating the nominal value by the GNP deflator (normalized at 1982). The price of dividends is accordingly defined to be $P_{2}=\left(u_{p}-u_{p}\right) p_{p} /\left(1-u_{l}\right), u_{p}$ is the effective personal tax rate on dividend income, $u_{z}$ is the effective tax rate on capital gains and $p_{p}$ is the GNP deflator. The series on the GNP deflator is obtained from the President's Economic Report (1988). The data relating to the effective tax rates on dividend income and on capital gains are obtained from Feldstein \& Jun (1987) for the years 1953 to 1984 . This has been extended to 1986 by using the values for 1984 .

Physical capital is defined to be the sum of the net capital stocks of structures and equipment. The deflator for physical capital is taken to be the price index for investment. This is obtained as the ratio of investment in current dollars to the investment in 1982 prices. All of the data on capital stocks and investment are obtained from Fixed Reproducible and Tangible Wealth in the U.S. 1925 - 1986. The post-tax purchase price of capital is calculated as the investment deflator multiplied by $\left(1-v_{k}-u_{c} z\right)$, where $v_{k}$ is the investment tax credit, $u_{c}$ is the corporate income tax rate and $z$ is the present value of capital consumption allowances.

Data on the investment tax credit from 1962 to 1980 are obtained from Jorgenson and Sullivan [1981]. Since the investment tax credit was only instituted in 1962 the value for $v_{k}$ before 1962 is taken to be zero. For $1981 v_{k}$ is assigned a value of $8 \%$, an average of $6 \%$ and $10 \%$, the investment tax credit for different classes of economic goods under the economic recovery act of 1981. For the years 1982 to 1985 a value of $7.5 \%$ is assigned so as to be in the same range of magnitude as the years preceding it. Data on the corporate income tax rate for the years 1947-1981 is also obtained from Jorgenson and Sullivan (1981), for 1982 the rate is obtained from Auerbach (1983), while for 1983-1985 the rate is 0.46 , which is equal to the rate for the period 1979-1982. The 
present value of capital consumption allowances is calculated as $z=\alpha\left(1-\theta v_{k}\right) /(r+\alpha)$, where, $\alpha$ is the ratio of capital consumption allowances to capital stock less treasury stock (at cost), obtained from the Quarterly Financial Report, $\theta$ is 0.5 in 1962-63 and zero everywhere else and $r$ is the rate of return on US Treasury securities 10 year maturity. ${ }^{16}$

The stock of debt is defined to be the sum of two components; installments due in more than one year on long-term loans from banks, and on other long-term debt. These series are end-ofperiod stocks for the fourth quarter and are obtained from the Quarterly Financial Report. The interest rate on debt is the rate of return on U.S. Treasury securities 10 year maturity. The discount rate is $p\left(1-u_{p}\right) /\left(1-u_{q}\right)$, where $p$ is the Moody's equity return on AAA corporations.

The estimation model consists of the post-tax net variable profit function (9), the output, labor and dividend variable profit component equation set (11), and the capital and debt equation set (13). There are six equations." The endogenous variables are post-tax net variable profit, output, labor, and the dividend variable profit components, capital and debt. In order to estimate the system of equations, errors must be added to the equations. Errors with zero expected value are added to equation sets (9) and (11). The errors associated with equation set (13) occur upon removal of the conditional expectations operator and the substitution of the realized values of the variables. These errors represent unanticipated information which becomes available after the time that the capital and debt decisions are made. Thus the conditional expected value of these errors is zero at the time of the capital and debt decisions. It is also assumed that the errors form a positive definite symmetric covariance matrix.

The estimation model consists of equations which contain expected future values of variables (see equation set (13)). In order to estimate these Euler equations, Hansen and Singleton (1982) developed a generalized method of moments estimator. Moreover, Pindyck and Rotemberg (1982) have shown that this estimator is equivalent to the nonlinear three stage least squares estimator (see Jorgenson and Laffont (1974)) when the errors are homoskedastic. The estimator involves the selection of instruments. Lagged values of relative prices, interest rate, post-tax variable profit, capital and debt are used as instruments. The estimator is consistent and efficient (for the set of instruments that are selected). 
The estimation results are presented in table I. The results show that the standard errors of the estimates are small relative to the estimates. The standard errors of each of the equations are also small relative to the mean of the endogenous variables. The correlation coefficients between the actual and predicted values of the endogenous variables are generally high. Using the J-statistic (see Jorgenson and Laffont (1974) and Pindyck and Rotemberg (1982), we can test the overidentifying restrictions of the model. This test permits us to determine whether or not production and financial decisions are based on optimizing behavior. The J-statistic is distributed as a chi-square with the degrees of freedom given by ( 13 instruments $) \times(6$ equations $)-(27$ parameters estimated $)=51$. In our model the value of $\chi_{s 1}^{2}$ at a $5 \%$ level of significance is 68.67 . The value of the J-statistic is 58.93 . Hence the null hypothesis, that the model is correctly specified, is accepted at the $5 \%$ level of significance. This implies that production and financial decisions are based on optimizing behavior.

The results from table I imply that the estimated magnitudes of net post-tax variable profit, output, labor and dividend variable profit components, capital and debt are positive at each point in the sample. This means that the monotenicity condition on the post-tax net variable profit function is satisfied as the function is increasing in the output price and capital, and decreasing in variable factor prices, dividend price and debt. In addition, we also find that the function is convex in prices.

\section{PRODUCTION, PROFITABILITY, AND DIVIDENDS}

In this section we investigate how financial considerations affect allocation decisions relating to output supply and input demands. In addition, we determine the resulting allocative effects on profitability for U.S. manufacturing. There are two issues that pertain to changes in financial position. The first centers on the production and profitability effects when the tax code is changed, thereby altering the opportunity cost of paying dividends. In this case, there is a change in the difference between personal income and capital gains tax rates. This differential reflects the price of dividends. The second issue concerns the effects of excessive debt. In this situation we consider changes in outstanding debt levels that have been determined by financing decisions in previous periods. This issue is only properly addressed in a short-run context, since debt is predetermined. 
14

TABLE I: Estimation Results

\begin{tabular}{|c|c|c|}
\hline Parameter & Estimate & Standard Error \\
\hline$\beta_{0}$ & 17.896 & 2.939 \\
\hline$\beta_{1}$. & 2.849 & 3.465 \\
\hline$\beta_{2}$ & -0.266 & 0.132 \\
\hline$\beta_{3}$ & 3.365 & 1.973 \\
\hline$\beta_{x}$ & -6.367 & 1.457 \\
\hline$\beta_{2}$ & 0.649 & 0.295 \\
\hline$\beta_{t}$ & 0.105 & $0.192 \mathrm{E}-01$ \\
\hline$\beta_{11}$ & -11.757 & 0.904 \\
\hline$\beta_{22}$ & $-0.969 \mathrm{E}-01$ & $0.551 E-02$ \\
\hline$\beta_{33}$ & 0.997 & 0.241 \\
\hline$\beta_{\mathbf{x x}}$ & 1.697 & 0.367 \\
\hline$\beta_{33}$ & $0.128 \mathrm{E}-01$ & $0.221 \mathrm{E}-01$ \\
\hline$\beta_{n}$ & $-0.190 \mathrm{E}-02$ & $0.687 \mathrm{E}-03$ \\
\hline$\beta_{1 X}$ & 1.506 & 0.665 \\
\hline$\beta_{18}$ & -0.119 & $0.634 \mathrm{E}-01$ \\
\hline$\beta_{\mathrm{ut}}$ & $-0.827 \mathrm{E}-01$ & $0.308 \mathrm{E}-01$ \\
\hline$\beta_{23}$ & $0.991 \mathrm{E}-01$ & $0.115 E-01$ \\
\hline$\beta_{2 x}$ & $0.288 \mathrm{E}-01$ & $0.288 E-01$ \\
\hline$\beta_{2 a}$ & $0.136 \mathrm{E}-01$ & $0.924 \mathrm{E}-02$ \\
\hline$\beta_{2}$ & $-0.775 E-03$ & $0.802 \mathrm{E}-03$ \\
\hline$\beta_{3 x}$ & -1.445 & 0.394 \\
\hline$\beta_{38}$ & $0.537 \mathrm{E}-01$ & $0.372 \mathrm{E}-01$ \\
\hline$\beta_{x}$ & $0.209 \mathrm{E}-01$ & $0.137 \mathrm{E}-01$ \\
\hline$\beta_{x=2}$ & -0.135 & $0.683 \mathrm{E}-01$ \\
\hline$\alpha_{x x}$ & $0.408 \mathrm{E}-03$ & $0.132 \mathrm{E}-03$ \\
\hline$\alpha_{m a}$ & $0.297 \mathrm{E}-03$ & $0.471 E-04$ \\
\hline$a_{x=}$ & $-0.110 \mathrm{E}-03$ & $0.623 \mathrm{E}-04$ \\
\hline Equation & Standard Error & Correlation Coefficient \\
\hline Variable Profit & 0.154 & 0.774 \\
\hline Output & 0.609 & 0.894 \\
\hline Dividends & $0.129 \mathrm{E}-01$ & 0.828 \\
\hline Labor & 0.223 & 0.790 \\
\hline Capital & 0.106 & 0.903 \\
\hline Bonds & $0.934 \mathrm{E}-02$ & 0.945 \\
\hline & J statistic & 58.93 \\
\hline
\end{tabular}


Thus the excessiveness of debt is defined relative to the level representing outcomes of past temporary equilibria.

Consider first the effects of changes in the price of dividends. Moreover, since changes in output and variable input prices affect dividend payments as well, we consider all short-run price elasticities. The price elasticities are denoted by,

(14.1) $c_{i j}=\left(\beta_{i j}+s_{i j} s_{j}-8_{i i} s_{i j}\right) / s_{i}$

$$
\mathrm{i}, \mathrm{j}=1, \ldots, \mathrm{n}+1
$$

where $e_{i j}$ is the elasticity of the ith quantity with respect to the jth price, $\delta_{i i}=1, \delta_{i j}=0$. Further, recall that $s_{i}>0$ for output and $s_{i}<0$ for dividends and variable inputs. ${ }^{\text {is }}$

The price elasticity results are presented in table II. From this table, increases in output price cause increases in output supply, variable input demands and dividend payments. In addition, increases in variable input and dividend prices decrease output supply, variable input demands and dividend payments. The results indicate that dividends are substantially more inelastic than output supply and variable input demands. Indeed, a one percent increase in the dividend price, that is, a one percent increase in the differential between the personal income and capital gains tax rates, cause dividend payments to decline by 0.4 percent. Moreover, dividend price changes elicit relatively more inelastic responses than changes in the other prices. A one percent increase in the price of dividends causes output supply and variable factor demands to fall, but the results are quite inelastic, ranging on average from 0.12 percent to 0.17 percent.

The price of dividends affects output supply, variable input demands and therefore variable profit. Noting that post-tax variable profit is defined as $\pi^{v}=\phi^{v}\left(1-s_{2}\right)$ where $s_{2}=-P_{2} D / \phi^{v}$ is the negative of the dividend component of variable profit, then

$$
e_{112}=\left[s_{2}\left(1-s_{2}\right)-\beta_{22} \gamma\left(1-s_{2}\right)\right.
$$

A one percent increase in the price of dividends reduces post-tax variable profit by 0.044 percent on average, with a sample standard deviation of 0.012 . The signaling benefits of dividends implies that profitability increases as dividend payments rise. Thus we can define dividend signaling benefits as 
TABLE II

Short-run Price Elasticities

(mean values and sample standard deviation in parentheses)

\begin{tabular}{lllll}
\hline Quantity & \multicolumn{3}{c}{ Price } \\
\hline & Output & Dividends & Labor & Intermediate \\
\hline Output & 5.274 & -0.117 & -2.718 & -2.439 \\
& $(1.410)$ & $(0.015)$ & $(0.252)$ & $(1.164)$ \\
Dividends & 7.033 & -0.376 & -3.502 & -3.155 \\
& $(1.189)$ & $(0.099)$ & $(0.276)$ & $(0.949)$ \\
Labor & 7.774 & -0.167 & -4.099 & -3.509 \\
& $(1.192)$ & $(0.016)$ & $(0.218)$ & $(0.985)$ \\
Intermediate & 10.896 & & & -7.688 \\
& $(0.522)$ & -0.157 & -3.050 & $(0.356)$ \\
& & $(0.017)$ & $(0.184)$ & \\
\hline
\end{tabular}


the percentage change in post-tax variable profit relative to the percentage change in dividends brought about from a one percent change in the opportunity cost of dividends. In other words

$$
e_{\mathrm{md}}=e_{\mathrm{ni}} / e_{22}
$$

where $e_{12}$ is from (14.2), and $e_{22}$ is from (14.1). The mean value of signaling benefits is 0.12 with a sample standard deviation of 0.043 . Thus a one percent increase in dividend payments leads to a 0.12 percent increase in post-tax variable profit for U.S. manufacturing.

The second issue relates to the effects of excessive debt. We investigate the effects of changes in outstanding debt on production, dividend payments and profitability. In addition, we compare these results to the effects of increases in asset or capital stock levels and the effects of technological change. The debt and capital elasticities and the effects of technological change on output supply, variable input demands, and dividend payments are given by

$$
c_{i j}=\beta_{i j} / s_{i}+e_{i j} \quad i=1, \ldots, n+1, j=B, K, t
$$

where $e_{\phi j}$ is the effect of $j$ on post-tax net variable profit. The results are found in table III.

Focusing on the issue of excessive debt, we find that increases in outstanding debt causes output supply, dividends and variable factor demands to decline. A one percent increase in debt leads to an approximately 0.05 percent decrease in the supply of output and the demand for variable inputs, while dividend payments decrease by 0.14 percent.

The agency cost of outstanding debt can be defined in terms of foregone profitability. In elasticity terms, the effect on post-tax variable profit is

$$
e_{x B}=\left[e_{6 B}\left(1-s_{2}\right)-\beta_{2 B}\right]\left(1-s_{2}\right)
$$

Our results show that the agency cost of outstanding debt is about 0.04 percent. The decline in profitability associated with excessive debt is consistent with the claim that increases in debt cause 
agency costs. These results for the U.S. manufacturing sector are similar to the results found by Kim and Maksimovic (1990) for the U.S. airline industry. They estimated that a one percent increase in debt caused variable cost to rise by 0.034 percent. In their model output was exogenous so that agency costs manifest themselves as a rise in variable cost. In our model output is endogenous so that agency costs appear as a reduction in variable profit.

Changes in the level of capital and technology also affect the short run equilibrium. It is interesting to note from table III that technological change mitigates the effect of excessive debt on dividend payments. In addition, our results show that the main element governing dividend growth is capital stock expansion. Dividends almost grow in proportion to capital. This result means that the dividend payout ratio, measured as dividends per dollar of capital stock is relatively constant for the U.S. manufacturing sector. Indeed the proportional growth of dividends in relation to capital can be considered an indication of the signaling role of dividends.

\section{ADJUSTMENT COSTS}

The dynamic features of the model are associated with the adjustment costs of capital accumulation and debt issues. The adjustment cost parameters appear in the Euler equations (equation set (13)) and their estimated values are presented in table I. The three adjustment cost parameters are $\alpha_{\mathrm{KX}}, \alpha_{\mathrm{BB}}, \alpha_{\mathrm{KB}}$. The own adjustment cost parameter estimates, $\alpha_{\mathrm{KK}}$, and $\alpha_{\mathrm{BB}}$, are positive as required. This result means that net capital investment increases marginal installation costs and new bond issues increase marginal agency costs. The cross adjustment cost parameter $\alpha_{\mathrm{KB}}$, is negative. This means that capital investment and bond issues are adjustment complements. As net capital investment occurs, the marginal agency cost of debt issues decreases. In other words, marginal agency costs are reduced when debt issues finance capital expansion. Adjustment costs are also convex in net capital investment and new bond issues, as $\alpha_{\mathrm{XK}} \alpha_{\mathrm{BB}}-\alpha_{\mathrm{XB}}^{2}>0$.

Debt issues increase agency costs and thereby influence the adjustment towards long run equilibrium. The agency costs associated with debt issues create a wedge between the contemporaneous and long run effects on profitability associated with bond financing. A measure 
TABLE III

Capital and Debt Elasticities and Rates of Technological Change (means and sample standard deviations in parentheses)

\begin{tabular}{llll}
\hline & Capital & Bonds & Technology \\
\hline Output & & & \\
& 0.838 & -0.052 & 0.089 \\
& $(0.186)$ & $(0.019)$ & $(0.007)$ \\
Dividends & 0.865 & -0.143 & 0.106 \\
& $(0.220)$ & $(0.029)$ & $(0.007)$ \\
Labor & 1.174 & -0.057 & 0.092 \\
& $(0.165)$ & $(0.019)$ & $(0.007)$ \\
Intermediate & 0.649 & -0.050 & 0.083 \\
& $(0.210)$ & $(0.018)$ & $(0.007)$ \\
Variable Profit & 0.641 & -0.037 & 0.099 \\
& $(0.211)$ & $(0.020)$ & $(0.007)$ \\
& & & \\
\hline
\end{tabular}


of the relative importance of the adjustment costs from debt issues can be derived from equation (13.2). In long run equilibrium when marginal debt adjustment cost equals zero, the reduction invariable profit from the agency cost of debt financing equals the differential between the post-tax rate of return to shareholders and the post-tax interest rate on bonds. The rate differential is defined to be $W_{B}(t)=p(t)\left(1-u_{p}(t)\right) /\left(1-u_{g}(t)\right)-r(t)\left(1-u_{c}(t)\right)$, where $r(t)\left(1-u_{c}(t)\right)=R(t), r$ is the interest rate on bonds and $u_{c}$ is the corporate income tax rate. The opportunity cost of funds (that is the rate of return to shareholders) must be sufficiently greater than the interest rate in order to pay for the marginal agency cost. Thus in the long run the ratio between the marginal agency cost and the net opportunity cost of funds $\left(\mathrm{W}_{\mathrm{B}}\right)$ equals unity. Thus the relative importance of debt adjustment cost in period $t$, when equilibrium deviates from the long run, is defined by the ratio of marginal adjustment cost to thenet opportunity cost of funds. This ratio is $\left[\alpha_{B B} \Delta B(t)+\alpha_{K B} \Delta K(t)\right]$ $\mathrm{W}_{\mathrm{B}}(\mathrm{t})$. Table IV shows that relative marginal debt adjustment cost averages 0.05 over the sample, with a maximum value of 0.48 and a minimum value of 0.005 . This result means that for a $\$ 1.00$ opportunity cost of debt (including interest) there is an additional adjustment cost of $\$ 0.05$.

The relative importance of capital adjustment cost can be seen from equation (13.1). In long run equilibrium from (13.1) with zero marginal adjustment cost the marginal profit associated with capital expansion equals the rental rate. The rental rate is defined as $W_{K}(t)=Q(t)\left(p(t)\left(1-u_{p}(t)\right) /\right.$ $\left.\left(1-u_{8}(t)\right)+8\right)$, and it is the long run opportunity cost of capital services. In a similar fashion to debt issues, the significance of the deviation from long run equilibrium can be measured by the ratio of marginal capital adjustment cost to the rental rate. This ratio is $\left[\alpha_{K K} \Delta K(t)+\alpha_{K B} \Delta B(t)\right] W_{K}(t)$. Table IV shows that relative capital adjustment cost averages 0.17 over the sample, with a maximum value of 0.48 and a minimum value of 0.014 . This means that for a $\$ 1.00$ rental of capital services there is an additional adjustment cost of \$0.17. Our results show that there are adjustment costs from financing capital expansion through debt issues and from installing the new capital. Thus if $\$ 1.00$ of capital services is financed through debt then adjustment costs on average, add another $\$ 0.22(\$ 0.05+\$ 0.17)$ to the cost of capital services. The findings associated with capital adjustment costs are consistent with Berndt and Morrison (1981), Pindyck and Rotemberg (1982), and Mohnen, 
TABLE IV

Relative Marginal Debt and Capital Adjustment Costs

\begin{tabular}{lll}
\hline Year & Bonds & Capital \\
\hline 1959 & 0.037 & 0.057 \\
1969 & 0.029 & 0.343 \\
1979 & 0.109 & 0.133 \\
1985 & 0.058 & 0.071 \\
mean & 0.047 & 0.166 \\
maximum & 0.481 & 0.476 \\
minimum & 0.005 & 0.014 \\
\hline
\end{tabular}


Nadiri and Prucha (1986) for the U.S. manufacturing sector, while this is the first time that debt adjustment costs have been estimated.

\section{SCALE, TECHNOLOGICAL CHANGE AND PRODUCTIVITY GROWTH}

Since outstanding debt and the price of dividends affect production, the degree of returns to scale and the rate of technological change also depend on debt and the dividend price. Returns to scale are defined as the proportional increase in output associated with variable and quasi-fixed input growth. Adhering to the standard definition of returns to scale, it is assumed that managerial in puts and technology do not change. Using the post-tax net variable profit function the degree of returns to scale is

$$
R R S=-\sum_{i=3}^{n \cdot 2} s_{j} / s_{1}+\partial \ln \phi^{2} / \partial \ln K_{K} / s_{1}
$$

recalling that $\mathrm{s}_{\mathrm{i}}<0 \mathrm{i}=2, \ldots, \mathrm{n}+2 .^{19}$ The first column of table $\mathrm{V}$ shows the degree of returns to scale. We estimate that for the U.S. manufacturing sector production is characterized by essentially constant returns to scale.

The elasticities of returns to scale with respect to the price of dividends and to outstanding bonds are presented in the second and third columns of table V. As dividend payments become more expensive or agency costs increase through higher debt, the degree of returns to scale declines. Since there are essentially constant returns to scale, a one percent increase in the price of dividends or outstanding debt decreases the degree of returns to scale on average by about two points. The rate of technological change, based on the net variable profit function, is given by

$$
\operatorname{RTC}=\left(\partial \ln \phi^{\gamma} / \partial t\right) / s_{1}
$$

Column four in table $\mathrm{V}$ shows that for U.S. manufacturing the average rate of technological change is 1.3 percent. In addition, the rate of technological change does not fluctuate over the sample period. $^{20}$ The elasticities of the rate of technological change with respect to the dividend price and 
TABLE V

Returns to Scale and Rates of Technological Change (sample standard deviations in parentheses)

\begin{tabular}{lcccccc}
\hline Year & RRS & RRS $_{\text {d }}$ & RRS $_{b}$ & RTC & RTC $_{d}$ & RTC \\
\hline 1959 & 0.903 & -0.017 & -0.019 & 0.016 & -0.0003 & 0.0002 \\
1969 & 0.922 & -0.017 & -0.019 & 0.014 & -0.0003 & 0.0003 \\
1979 & 0.973 & -0.013 & -0.014 & 0.010 & -0.0002 & 0.0001 \\
1985 & 0.977 & -0.013 & -0.013 & 0.010 & -0.0002 & 0.0001 \\
& & & & & & \\
Mean & 0.933 & -0.016 & -0.017 & 0.013 & -0.0003 & 0.0002 \\
& $(0.036)$ & $(0.002)$ & $(0.003)$ & $(0.002)$ & $(0.00007)$ & $(0.00006)$ \\
& & & & & & \\
\hline
\end{tabular}


outstanding debt are presented in the last two columns of table $\mathrm{V}$. We find that the dividend price and outstanding debt generate rather small effects on the rate of technological change. In addition, these effects almost offset each other. Thus a lowering of the dividend price (for example through a decrease in the personal income tax rate) increases the rate of technological change, but this impact can be neutralized if technological change is accompanied by growing debt.

Total factor productivity (TFP) growth is an indicator of dynamic efficiency and represents the difference between output and input growth rates. Traditionally this difference arises from technological change and scale effects. We now show how the signaling benefits of dividends and the agency costs of debt affect TFP growth. Debt and dividend affect TFP growth because debt issues and the price of dividends influence profitability over time through changes in the growth rates of output and variable inputs. By definition,

$$
T F P G=\operatorname{din} y-\sum_{i=3}^{n+2}\left(P_{i} v_{i} / c\right) d \ln v_{i} \cdot\left(W_{K} K / c\right) \operatorname{din} K
$$

where $c=\sum_{i=3}^{n+2} P_{i} v_{i}+W_{k} K$ is total cost. ${ }^{21}$ By taking a total differential of both the net variable profit function (equation (8) net of adjustment costs) and the definition of net variable profit $\left(\phi^{2}=\right.$ $\left.P_{1} y=\sum_{i=3}^{n+2} P_{i} v_{i}-P_{2} D\right)$, and using Hotelling's Lemma (see Diewert (1982)), we get

$$
\begin{aligned}
s_{1} d \ln y+\sum_{i=3}^{n+2} s_{i} d \ln v_{i} & +s_{2} d \ln D=\left(\partial \ln \phi^{\nu} / \partial \ln K\right) d \ln K \\
& +\left(\partial \ln \phi^{\nu} / \partial \ln B\right) d \ln B+\left(\partial \ln \phi^{\nu} / \partial t\right)
\end{aligned}
$$

where $s_{1}=P_{1} y / \phi^{\nu}>0, s_{i}=-P_{i} v_{i} / \phi^{\nu}<0, i=3, \ldots, n+2$ and $s_{2}=-P_{2} D / \phi^{\nu}<0$ are the net variable profit components of output, variable inputs and dividends. Next by multiplying both sides of (19) by $\phi^{\mathrm{\gamma}} / \mathrm{c}$ and adding (18) to both sides yields 


$$
\begin{aligned}
& \mathrm{TFPG}=\left(1-\left(\phi^{\gamma} / c\right) s_{1}\right) \ln y+\left(\phi^{\gamma} / c\right) \partial \ln \phi^{\gamma} / \partial t+\left(\phi^{\gamma} / c\right)\left(\left(\partial \ln \phi^{\gamma} / \partial \ln K\right)\right. \\
& \left.-\left(W_{K} K / \phi^{v}\right)\right) d \ln K+\left(\phi^{v} / c\right) s_{2} d \ln D+\left(\phi^{v} / c\right)\left(\partial \ln \phi^{v} / \partial \ln B\right) d \ln B
\end{aligned}
$$

Thus there are five componen ts to TFP growth. The first term reflects the scale effect, the second term represents technological change, the third term captures the capital adjustment effect, the fourth term represents the signaling effect arising from dividend payments and the fifth term shows the agency cost effect associated with debt financing. ${ }^{22}$ If dividends are growing, then the signaling benefits associated with this growth imply that there are TFP gains. In addition, if bond issues are growing, then agency costs imply that there are TFP losses.

Table VI shows TFP growth rates and their decomposition over the period 1956-1985 for U.S. manufacturing. ${ }^{23}$ The signaling effect contributes to the average annual growth rate of TFP by 0.0005 or 4.2 percent of the total. The agency cost effect reduces the TFP growth by .0004 or by 3.3 percent of the total. Kim and Maksimovic (1990) decompose TFP growth for the U.S. airline industry based on a variable cost formulation. They do not have a dividend signaling component, but their agency cost component reduces airline TFP growth by 2.6 percent. This figure is consistent with our agency cost component for manufacturing. However, we estimate that financial decisions not only reduce TFP growth through bond issues, but also increase TFP growth through the signaling benefits of dividend payments. Indeed, we estimate that the dynamic efficiency effects associated with dividend payments and bond issues nearly offset each other for the U.S. manufacturing sector.

\section{CONCLUSION}

In this paper we estimated a model with debt agency costs and dividend signaling benefits that affects production, profitability, and productivity growth. The model is applied to the U.S. manufacturing sector. Signaling benefits and agency costs are measured by their impact on profitability. A one percent increase in dividends causes post-tax variable profit to rise by 0.12 percent, while a one percent increase in outstanding debt causes variable profit to decline by 0.04 percent. 


\section{TABLE VI}

Total Factor Productivity Growth and Decomposition

(Average Annual Growth Rates)

\begin{tabular}{lllllll}
\hline Year & TFPG & Scale & Tech. Change & Cap. Adj. & Dividends & Debt \\
\hline $1960-65$ & 0.014 & -0.005 & 0.018 & -0.0003 & 0.0007 & -0.0006 \\
$1966-71$ & 0.013 & -0.005 & 0.016 & 0.002 & 0.0004 & -0.0004 \\
$1972-77$ & 0.013 & -0.0009 & 0.013 & 0.002 & 0.0002 & -0.0007 \\
$1978-83$ & 0.010 & -0.0002 & 0.011 & -0.0001 & 0.0001 & -0.0006 \\
$1956-85$ & 0.012 & -0.003 & 0.014 & 0.0006 & 0.0005 & -0.0004 \\
\hline
\end{tabular}


Agency costs, in conjunction with capital installation costs, prevent the manufacturing sector from costlessly adjusting to long-run equilibrium. The deviation from long-run equilibrium is reflected by the result that for an additional dollar obtained by issuing debt and used to finance capital expansion, adjustment costs are $\$ 0.22$. This amount consists of $\$ 0.05$ attributable to the agency cost from bond issues, and the remaining $\$ 0.17$ arises from capital installation costs.

The existence of signaling benefits and agency costs imply that output supply, and variable input demands, are affected by financial considerations. In the short run a one percent increase in debt causes output supply and variable input demands to decline by 0.05 percent, while a one percent increase in the price of dividends generates about three times the effect on production. Moreover, in the short run, more expensive dividends and excessive debt cause about the same reduction in variable profit. A one percent increase in outstanding debt or dividend price reduces post-tax variable profit by approximately 0.04 percent for the U.S. manufacturing sector.

The dynamic efficiency of the manufacturing sector is affected by debt agency costs and dividend signaling benefits. Signaling benefits contribute about 4.2 percent of the growth in productivity, while agency costs reduce efficiency by 3.3 percent. Thus, while financial considerations do in fact influence dynamic efficiency for the manufacturing sector, the efficiency enhancing signaling benefits from dividends are nearly offset by the efficiency reducing agency costs from bond financing. It would be interesting to investigate in further research whether these efficiency offsetting financial effects operate in different industries and in different countries. 


\section{REFERENCES}

Auerbach, A.J., 1979, "Wealth Maximization and the Cost of Capital," Quarterly Journal of Economics, 93, 433-446.

1983, "Corporate Taxation in the United States," Brookings Papers on Economic Activity, 2, 451-505.

Berndt, E.R. and C. Morrison, 1981, "Short-Run Labor Productivity in a Dynamic Model," Lournal of Econometrics, 16, 339-365.

Bernheim, B.D., 1991, "Tax Policy and the Dividend Puzzle," Rand Journal of Economics, 22, 455476.

Bernstein, J.I., 1992, "Price Margins and Capital Adjustment: Canadian Mill Products and Pulp and Paper Industries," forthcoming International Journal of Industrial Organization.

Bernstein, J.I. and M.I. Nadiri, 1988, "Corporate Taxes and Incentives and the Structure of Production: A Selected Survey," in The Impact of Taxation on Business Activity, J.M. Mintz and D.D. Purvis, eds., Kingston, Ontario: John Deutsch Institute for the Study of Economic Policy.

Bhattacharyya, S., 1979, "Imperfect Information, Dividend Policy, and the 'Bird in the Hand' Fallacy," Bell Joumal of Economics, 10, 259-270.

Brander, J.A. and B.J. Spencer, 1989, "Moral Hazard and Limited Liability: Implications for the Theory of the Firm," International Economic Review, 30, 833-851.

Caves, D.H., L. R. Christensen, and W.E. Diewert, 1982, "The Economic Theory of Index Numbers and the Measurement of Input, Output and Productivity," Econometrica, 50, 1393-1414.

Diewert, W.E., 1982, "Duality Approaches to Microeconomic Theory," in Handbeok of Mathematical Economics, vol. 2, K. Arrow and M. Intriligator eds., Amsterdam: NorthHolland.

..--.--.-, 1989, "'The Measurement of Productivity," UBC Discussion Paper 89-04.

Fazzari, S., R. Hubbard, and B. Petersen, 1988, "Financing Constraints and Corporate Investment," Brookings Papers on Economic Activity, W. Brainard and G. Perry, eds., Washington: The 
Brookings Institution.

Feldstein, M. and J. Jun, 1987, "The Effects of Tax Rules on Non-Residential Fixed Investment: Some Preliminary Evidence for the 1980's, "in M. Feldstein, ed., The Effects of Taxation on Capital Accumulation, Chicago: University of Chicago Press.

Greenwald, B.C., M. Kohn, and J.E. Stiglitz, 1990, "Financial Market Imperfections and Productivity Growth," Joumal of Economic Behavior and Organization 13, 321-345.

Gullickson, W. and M.J. Harper, 1986, "Multifactor Productivity Measurement for Two-Digit Manufacturing Industries," paper presented at the meetings of the Western Economic Association, San Francisco, July 1-5.

Hulten, C. and J. Robertson, 1982, "Corporate Tax Policy and Economic Growth: An Analysis of the 1981 and 1982 Tax Acts," in Managerial lssues in Productivity Analysis. Studies in Productivity Analysis, vol. 5, A. Dogramaci and N. Adam, eds., Martinus Nijhofr, Boston.

Jensen, M.C. and W. Meckling, 1976, "Theory of the Firm: Managerial Behavior, Agency Costs and Capital Structure," Joumal of Einancial Economics, 3, 305-360.

Jorgenson, D.W., 1986, "Econometric Methods for Modelling Producer Behavior," in Handbook of Econometrics, vol. 3, ch. 31, Z. Griliches and M. Intriligator, eds., Amsterdam: NorthHolland, 1841-1915.

Jorgenson, D.W. and M.A. Sullivan, 1981, "Inflation and Corporate Capital Recovery," in Depreciation, Inflation, and Taxation of Income from Capital, ed. C. R. Hulten, Urban Institute, Washington, D.C.

Kim, M. and V. Maksimovic, 1990, "Technology, Debt, and the Exploitation of Growth Options," Journal of Finance, 45: 795-816.

King, M.A., 1977, Public Policy and the Corporation, London: Chapman and Hall.

Leland, H.E., and D.H. Pyle, 1977, "Informational Asymmetries, Financial Structure, and Financial Intermediation," Journal of Einance, 32, 371-387.

Maksimovic, V., 1986, "Optimal Capital Structure in a Stochastic Oligopoly," Unpublished doctoral dissertation, Harvard University.

Mohnen, P., M.I. Nadiri, and I. Prucha, 1986, "R\&D, Production Structure and Productivity Growth in the U.S., Japanese, and German Manufacturing Sectors," European Economic Review, 30, 749-772. 
Morrison, C., 1992, "Unraveling the Productivity Growth Slowdown in the U.S., Canada and Japan: The Efrects of Subequilibrium, Scale Economies, and Markups," forthcoming Review of Economics and Statistics.

Myers, S.C., 1977, "Determinants of Corporate Borrowing," Joumal of Einancial Economics, 5, 147-175.

Myers, S.C. and N.S. Majluf, 1984, "Corporate Financing and Investment Decisions when Firms Have Information Investors Do Not Have," Journal of Einancial Economics, 11, 187-221.

Pindyck, R.S. and J.J. Rotemberg, 1982, "Dynamic Factor Demands and the Effects of Energy Price Shocks," American Economic Review, 30, 749-772.

-......-., 1983, "Dynamic Factor Demands Under Rational Expectations," Scandinavian Journal of Economics 85 (2), 223-238.

Poterba, J. and L.H. Summers, 1985, "The Economic Effects of Dividend Taxation," in Recent Advances in Corporate Finance, E.I. Altman and M.G. Subrahmanyam eds., Homewood, IL: Richard D. Irwin.

Ross, S.A., 1977, "The Determination of Financial Structure: The Incentive Signalling Approach," Bell Journal of Economics, 8, 23-40.

Stiglitz, J.E. and A.M. Weiss, 1981, "Credit Rationing in Markets with Imperfect Formation," American Economic Review, 71, 393-410. 


\section{NOTES}

"The authors would like to thank Bhaswar Mukhopadhyay for his excellent research assistance. We would also like to thank members of the NBER productivity group and Fumio Hayashi for helpful comments and suggestions on an earlier version of the paper. We also acknowledge support from the C.V. Starr Center for Applied Economics of New York University.

'This literature generally relates to single equation models. In addition, those models do not use duality theory in the integration of production and financing decisions.

2See Diewert (1982) for a survey of duality theory.

${ }^{3} \mathrm{Kim}$ and Maksimovic (1990) have utilized duality theory in a short-run equilibrium context.

The production function has the usual properties of increasing at a decreasing rate in the inputs, decreasing at a decreasing rate in the changes to the capital input. The model can easily be generalized to multiple outputs, multiple capital inputs, and multiple managerial inputs.

'See Morrison and Berndt (1981), Pindyck and Rotemberg (1982), and Mohnen, Nadiri, and Prucha (1986) for empirical studies relating adjustment costs to production in the U.S. manufacturing sector.

'It should be noted that the managerial cost function leads to a stylized representation of the interaction between production and financial decisions. Like other empirical studies, we do not derive the functional link between production and financial decisions.

'In terms of managerial cost, since $\mu$ is the factor price of managerial input and cost functions are homogeneous of degree one in factor prices, $c^{-}=H(\mu, V)=\mu H(V)$ where $V$ is the vector of non-price variables affecting managerial cost. The expression $\mu \mathrm{H}(\mathrm{V})$ is the managerial cost function.

'Clearly, it is possible to have output, capital and variable input quantities affect the $\mathrm{H}$ function in equation (2). For example, agency costs could manifest themselves in terms of increases in outstanding debt relative to the capital stock. However, we would still obtain a production/managerial function as is defined by equation (3).

'See Bernstein and Nadiri (1988) for the derivation of the post tax purchase price of capital.

${ }^{10}$ This function has the same properties as a variable profit function (see Diewert (1982)).

"The monotonicity and concavity conditions of the net variable profit function with respect to the prices are not imposed by us but are chocked from the estimation results. In addition, the (t) notation is generally now omitted.

${ }^{12}$ See Morrison and Berndt (1981) and Mohnen, Nadiri, and Prucha (1986) in the context of quasi-fixed factors.

${ }^{13}$ Equations (9) and (10) can be combined by a suitable reinterpretation of the $\alpha$ parameters reflecting adjustment costs as the proportional reduction in normalized net variable profit. 
"The $n+2$ variable profit component, which relates to the normalizing variable factor, can be eliminated since $s_{n+2}=1 \cdot \sum_{i=1}^{n+1} s_{i}$.

${ }^{13}$ It is assumed that there is a non-binding constraint that $\Delta S_{a}(t) \geq 0$, share repurchases are not permitted. This assumption is satisfied for the manufacturing sector.

${ }^{16}$ The constant $\theta$ is defined by the Long Amendment, according to which firms had to reduce the depreciable base of the assets by the amount of the ITC (See Hulten and Robertson (1982)).

${ }^{17}$ The adjustment cost function is not estimated as a separate equation because the parameters are contained in the capital and debt equations. In addition, there are no data on adjustment costs.

${ }^{12}$ The price elasticities associated with the $n+2$ variable factor, which is the intermediate input, is calculated as a residual. It should be noted that all elasticities use the predicted values of the endogenous variables from the estimation model. In other words, we use the fitted values for output supply, labor and intermediate demands, and dividend payments.

${ }^{19}$ Note that in the definition of returns to scale, debt and capital are calculated at their existing levels. Also recall that $\mathrm{i}=3, \ldots, \mathrm{n}+2$ represents the variable factors, $\mathrm{i}=1$ is output and $\mathrm{i}=2$ is dividends, which does not enter the definition of returns to scale.

${ }^{20}$ The definition of the rate of technological change is the output-based concept. There is also an input-based definition of the rate of technological change, but the two measures are equal when there is constant returns to scale (see Caves, Christensen and Diewert (1982)).

${ }^{21}$ See Diewert (1989) for a survey of the issues relating to the definition and measurement of TFP growth.

${ }^{2}$ Bernstein (1992) and Morrison (1992) show how capital adjustment costs affect TFP growth.

${ }^{2}$ Table 6 is a Tomqvist approximation to equation (20) (see Diewert (1989)) . 